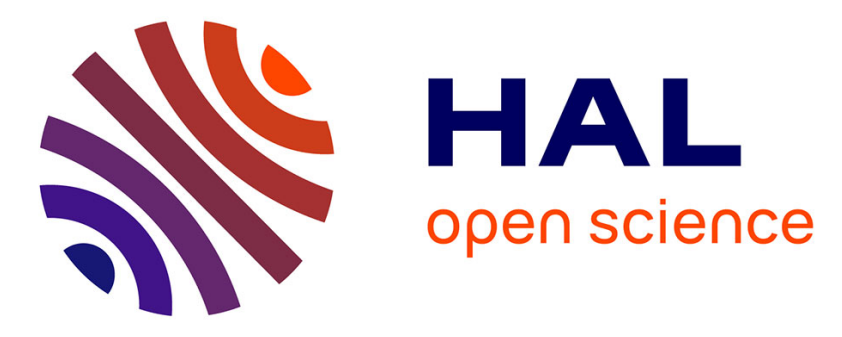

\title{
Strategies for embolization of direct arteriovenous shunts in brain arteriovenous malformations
}

Frédéric Clarençon, Eimad Shotar, Stéphanie Lenck, Mathilde Aubertin, Kevin Premat, Anne-Laure Boch, Nader-Antoine Sourour

\section{- To cite this version:}

Frédéric Clarençon, Eimad Shotar, Stéphanie Lenck, Mathilde Aubertin, Kevin Premat, et al.. Strategies for embolization of direct arteriovenous shunts in brain arteriovenous malformations. Journal of Neurointerventional Surgery, 2021, pp.neurintsurg-2021-017317. 10.1136/neurintsurg-2021-017317 . hal-03207936

\section{HAL Id: hal-03207936 \\ https://hal.sorbonne-universite.fr/hal-03207936}

Submitted on 26 Apr 2021

HAL is a multi-disciplinary open access archive for the deposit and dissemination of scientific research documents, whether they are published or not. The documents may come from teaching and research institutions in France or abroad, or from public or private research centers.
L'archive ouverte pluridisciplinaire HAL, est destinée au dépôt et à la diffusion de documents scientifiques de niveau recherche, publiés ou non, émanant des établissements d'enseignement et de recherche français ou étrangers, des laboratoires publics ou privés. 


\section{Strategies for Embolization of Brain Arteriovenous Malformations' Direct Arteriovenous Shunts}

Frédéric Clarençon, MD, $\mathrm{PhD}^{1,2,3}$, Eimad Shotar, $\mathrm{MD}^{2}$, Stéphanie Lenck ${ }^{2}$, MD, Mathilde Aubertin, MD ${ }^{2}$, Kévin Premat, MD ${ }^{1,2}$, Anne-Laure Boch, MD ${ }^{4}$ and Nader-Antoine Sourour, $\mathrm{MD}^{2}$

1 . Sorbonne University. Paris. France

2. Department of Neuroradiology. Pitié-Salpêtrière Hospital. APHP. Paris. France

3 . GRC BioFast. Paris VI University. Paris. France.

${ }^{4}$. Department of Neurosurgery. Pitié-Salpêtrière Hospital. APHP. Paris. France 
Corresponding author:

Pr Frédéric Clarençon (MD, PhD)

Department of Neuroradiology. Pitié-Salpêtrière Hospital.

47, Bd de l'Hôpital. 75013. Paris. FRANCE

Tel: + 33142163599

Fax: +33142163595

e-mail: fredclare5@gmail.com

Word count: 122

Number of figures: 0

Number of videos: 1

Number of tables: 0

\section{Acknowledgment:}

None

Funding: none

\section{Disclosures:}

Pr F. Clarençon reports conflict of interest with Medtronic, Guerbet, Balt Extrusion, Penumbra (payment for readings; non-related to the study), Codman Neurovascular and Microvention (core lab; non-related to the study).

Dr Nader-Antoine Sourour is consultant for Medtronic, Balt Extrusion, Microvention. The other authors report no conflict of interest concerning the materials or methods used in this study or the findings specified in this paper. The manuscript is not supported by industry. 


\begin{abstract}
Intranidal direct arteriovenous (AV) shunts are non-rarely observed in brain arteriovenous malformations (bAVMs). ${ }^{1}$ The endovascular treatment of such direct AV shunts may be challenging. Indeed, there is a significant risk of venous migration of the embolic agent used to occlude the AV shunt, leading to a subsequent risk of nidus bleeding due to impairment (slowdown or even occlusion) of the bAVM's venous drainage. ${ }^{2}$

Various endovascular techniques have been developed to avoid the risk of such inopportune impairment of the venous drainage during attempts to occlude a direct intranidal AV shunt. ${ }^{3-5}$ We present in this Technical video (Video 1) different endovascular strategies to occlude such direct AV shunts using dual lumen balloons with various liquid embolic agents, or using occlusion plugs.
\end{abstract}

\title{
References
}

${ }^{1}$. Krings T, Hans FJ, Geibprasert S, Terbrugge K. Partial "targeted" embolisation of brain arteriovenous malformations. Eur Radiol. 2010;20(11):2723-31. doi: 10.1007/s00330-0101834-3.

2. Baharvahdat H, Blanc R, Termechi R, Pistocchi S, Bartolini B, Redjem H, Piotin M Hemorrhagic complications after endovascular treatment of cerebralarteriovenous malformati ons. AJNR Am J Neuroradiol. 2014;35(5):978-83. doi: 10.3174/ajnr.A3906. 3 . Andreou A, Ioannidis I, Nasis N. Transarterial balloon-assisted glue embolization of highflow arteriovenous fistulas. Neuroradiology. 2008;50:267-72.

${ }^{4}$. Shotar E, Al Raaisi A, Lenck S, et al. Injection of N-butyl Cyanoacrylate Through a DualLumen Balloon for Embolization of High-flow Intranidal Fistulas in Brain Arteriovenous Malformations: Technical Note. Clin Neuroradiol. 2020;30(2):313-319. doi: 10.1007/s00062019-00780-6.

5. Guglielmi G, Viñuela F, Duckwiler G, Dion J, Stocker A. High- flow, small-hole arteriovenous fistulas: treatment with electrodetachable coils. AJNR Am J Neuroradiol. 1995; 16:325-8.

\section{Contributorship statement:}

Frédéric Clarençon: Manuscript redaction, video preparation

Eimad Shotar: Manuscript preparation, critical review of the manuscript

Stéphanie Lenck: Critical review of the manuscript

Mathilde Aubertin: Data collection, critical review of the manuscript

Kevin Premat: Critical review of the manuscript

Anne-Laure Boch: Critical review of the manuscript

Nader-Antoine Sourour: Data collection, Critical review of the manuscript 